\title{
EDUCATIONAL MISMATCHES IN THE EU: IMMIGRANTS vS. NATIVES
}

\author{
Sandra Nieto (AQR-IREA, UB) \\ Alessia Matano (AQR-IREA, UB) \\ Raul Ramos (AQR-IREA, UB)
}

Purpose: The purpose of this paper is to analyse and explain the factors contributing to the observed differences in skill mismatches (vertical and horizontal) between natives and immigrants in EU countries.

Design/methodology/approach: Using microdata from the 2007 wave of the Adult Education Survey (AES), different probit models are specified and estimated to analyse differences in the probability of each type of skill mismatch between natives and immigrants. Yun's decomposition method is used to identify the relative contribution of characteristics and returns to explain the differences between the two groups..

Findings: Immigrants are more likely to be skill mismatched than natives. The difference is much larger for vertical mismatch, wherein the difference is higher for immigrants coming from non-EU countries than for those coming from other EU countries. We find that immigrants from non-EU countries are less valued in EU labour markets than natives with similar characteristics - a result that is not observed for immigrants from EU countries. These results could be related to the limited transferability of human capital acquired in non-EU countries.

Social implications: The findings suggest that specific programs to adapt immigrants' human capital acquired in the home country are required to reduce differences in the incidence of skill mismatch and better integration into EU labour markets.

Originality: This research is original, because it distinguishes between horizontal and vertical mismatch -an issue that has not been considered in the literature on differences between native and immigrant workers - and due to the wide geographical scope of our analysis, which considers EU and non EU-countries.

Keywords: Immigrant overeducation, vertical mismatch, horizontal mismatch, human capital transferability. 


\section{INTRODUCTION AND OBJECTIVES}

The European Neighbourhood Policy (ENP) was launched in the early 2000s and relaunched in 2010 with the aim of strengthening relationships between the EU and its neighbouring countries. Mobility and migration policies are a fundamental part of most bilateral action plans, but most measures focus on asylum and visa and border policies and pay very little attention to integration policies in host countries. Even if mobility is supposed to be temporary, the ENP should also encourage favourable legislation for immigrants in host countries, particularly for the highly qualified. However, recent literature (Aleksynska and Tritah, 2013; Piracha and Vadean, 2013; Chiswick and Miller, 2010 among others) highlights the relevance of educational mismatch among immigrants and its negative consequences in terms of labour market outcomes (mainly wages). In fact, in recent decades, the improvement of the average attained education level of the population in all economies has contributed to a growing literature focused on the analysis of educational mismatch. Most studies have focused on the effects of vertical mismatch, which deems that a worker is overeducated when his/her level of education is higher than the level of education required by his/her job ${ }^{1}$. It is generally found that overeducated workers receive lower wages and have lower levels of job satisfaction than properly educated workers with the same level of education (for a review, see Hartog, 2000 and Leuven and Oosterbeek, 2011). A different strand of literature has focused on immigrants' occupational downgrading in the host country (see Akresh, 2008; Carneiro et al., 2012; Danzer and Dietz, 2014) - a phenomenon that is also related to vertical mismatch.

On the other hand, horizontal mismatch has been scarcely analysed in existing literature. Horizontal mismatch compares the match between worker type or field of education and that which is required by their jobs; a worker is affected by horizontal mismatch when his/her field of education differs from that which is required by his/her job ${ }^{2}$. It is found that horizontal mismatch also has a negative effect on workers' wages (Robst, 2007; Wolbers, 2003), and it appears to exceed the wage penalty associated with overeducation (Robst, 2008; Nordin et al., 2008). However, the little attention to horizontal mismatch analysis may be explained by a lack of databases including information about workers' fields of education, which is required to measure that indicator. On the other hand, such a database could carry

\footnotetext{
${ }^{1}$ For instance, a worker is overeducated when he/she holds an undergraduate degree and is working as a salesperson-an occupation for which the average level of education is primary education.

2 For instance, a worker is horizontal mismatched when he/she holds an undergraduate degree on statistics and ends up working as a journalist.
} 
sample restrictions problems, because field of education is only defined for workers with more than secondary education.

To analyse the role of vertical and horizontal educational mismatches on native and immigrant populations, we use microdata from the Adult Education Survey, a source that allows us to measure both vertical and horizontal mismatches. To the best of our knowledge, no previous studies have analysed both types of educational mismatches separately for natives and immigrants using homogeneous information for a wide group of EU countries. Taking this into account, the aim of this paper is twofold. First, we examine the determinants of situations of vertical or horizontal mismatch for natives and immigrants from EU countries and from nonEU countries, focusing on the process of assimilation. Second, we identify the explanatory factors for the observed differences in the probability of being mismatched, considering natives and both EU and non-EU immigrants.

The rest of the paper is organized as follows. Section 2 is a literature review about immigration and educational mismatch. Section 3 describes the database and defines the variables of interest. Section 4 presents descriptive evidence of the incidence of vertical and horizontal mismatches for natives and immigrants, focusing also on the analysis of the immigrant assimilation process. Section 5 explains the applied methodology and shows the results. Section 6 summarises the findings of previous sections and provides our main policy conclusions.

\section{BACKGROUND}

Human capital is one of the key factors in the determination of most of labour market outcomes (Card, 1999; Psacharopoulos and Patrinos, 2004). Consistent with this perspective, the analysis of the situation of immigrants within their host countries' labour markets has also focused on their human capital. In particular, the two main empirical results from this literature-the presence of a significant initial wage gap relative to native-born workers and the rapid wage growth from the moment of arrival-can basically be explained by their human capital. Further, human capital partially explains most differences between immigrants and natives in terms of participation in the labour market and job quality, among other factors. Thus, the disadvantage experienced by immigrants when they arrive in a new country can generally be attributed to the limited transferability of the human capital they have acquired in their home country. The reason may lie in the lower quality of the educational system in the country of origin or in different cultural backgrounds. Whatever the case, the relevant fact is 
that newly arrived immigrants seem to lack human capital adequate to the needs of the host country's labour market (Chiswick, 1978; Chiswick and Miller, 1985, 2009; Friedberg, 2000). Moreover, the explanatory factor behind the rapid growth in immigrant labour market outcomes over time, especially in wages, can be found in the accumulation of different types of human capital in the host country, which is particularly significant in the first years of residence (i.e., knowledge of the host country language). It is also noteworthy that this rapid growth in labour market outcomes generally leads to assimilation with the native population (Chiswick, 1978; Baker and Benjamin, 1994; Chiswick and Miller, 1995; Bell, 1997; among others).

Within this body of literature, recent studies have focused on vertical mismatch and, more specifically, on the level of overeducation. Although an extensive body of research has analysed overeducation ${ }^{3}$ since the seminal contributions of Freeman (1976) and Duncan and Hoffman (1981), only recently has the literature considered differences between natives and immigrants. ${ }^{4}$

The idea underpinning the new literature on overeducation is that the imperfect portability of human capital acquired in origin countries forces immigrants to accept jobs requiring lower qualifications than those they have acquired, making them formally overeducated workers. ${ }^{5}$ The main outcomes of recent studies can be summed up in two empirical regularities. First, there is evidence of a greater incidence of overeducation among immigrants than among the native population. Second, the gap in overeducation of immigrants with respect to the native population is reduced as their stay in the new country is prolonged, i.e., the phenomenon of assimilation takes place in overeducation (in a similar way to the earnings assimilation phenomenon ${ }^{6}$ ).

The literature on immigrant assimilation started with Chiswick (1978) who explains the lower marginal returns of immigrant human capital in the USA by the limited portability of their human capital. The results obtained for other economies confirm the differences between natives and immigrants in terms of the remuneration of their human capital, and also show the existence of assimilation processes (Chiswick and Miller, 1995, for Australia; Baker

\footnotetext{
${ }^{3}$ Surveys by Hartog (2000), Rubb (2003), and McGuiness (2006) summarise the main findings of this literature.

${ }^{4}$ See for instance, Piracha and Vadean (2013); Dustman and Glitz (2011); and Leuven and Oosterbeek (2011)

5 Possible differences in the quality of different educational systems limit the comparison between native and immigrants workers. Nevertheless, many other factors (including a partial knowledge of the language, qualifications not being recognised, and studies adapted to the new labour market) reduce the expected productivity of immigrants, leading them to accept lower-paid jobs.

${ }^{6}$ As previously mentioned, immigrants' earnings tend to converge to natives' earnings, reducing the wage gap as the number of years of residence in the host country increases.
} 
and Benjamin, 1994, for Canada; Bell, 1997, for the UK; Schmidt, 1992, and Constant and Massey, 2003, for Germany; Longva and Raaum, 2003, for Norway). Shields and Wheatley Price (1998) and Friedberg (2000) also obtain interesting results separating the education acquired by immigrants in their country of origin from the education acquired in the country of destination. They find that human capital imported from culturally distant countries receives lower remuneration than human capital acquired in the country of destination, and this remuneration differs depending on the characteristics of the origin country. Thus, the greater the distance in terms of language, culture, and economic development, the less portable the human capital acquired abroad becomes, and the greater the initial inequality in the job market compared to members of the native population. Nonetheless, Duleep and Regets (1997) find that those immigrants characterised as having less portable human capital show a higher speed of assimilation.

Other interesting results have been found when overeducation has been explicitly introduced into the analysis of the differences between natives and immigrants. Most of the literature concludes that immigrants have a higher rate of overeducation than natives (Chiswick and Miller, 2010). For instance, using data from Australia, Kler (2006) and Green et al. (2007) point out that the incidence of overeducation is higher among immigrants from nonEnglish-speaking countries, and they also show lower returns for overeducation. In the case of the United Kingdom, Lindley and Lenton (2006) find a higher incidence of overeducation not just among immigrants but also for non-white members of the native-born population. Using data from the United States, Chiswick and Miller (2008) claim that the educational mismatch explains almost two-thirds of the differences in human capital returns between natives and immigrants.

In the analysis of the incidence of overeducation among immigrants, other results related to the degree of transferability of human capital acquired in the origin country and the process of assimilation are also interesting. In particular, Chiswick and Miller (2007) find that the greater the work experience in the country of origin, the greater the probability of overeducation in the United States, which indicates low transferability not only of schooling but also of work experience acquired in origin countries. Sanromá et al. (2008) point out that immigrants living in Spain accumulate knowledge and experience that are perfectly adapted to the local labour market, thus making for an easier assimilation process that reduces the intensity of overeducation. However, the pace of assimilation is notably slow-around 15 years of living in Spain would be necessary to eliminate the educational mismatch-and differs depending on the origin country. Using data from New Zealand, Poot and Stillman (2010) also 
conclude that it is relevant to control for origin heterogeneity when analysing the pace of assimilation of immigrants in terms of overeducation. Finally, Nielsen (2007) shows that overeducation in Denmark affects immigrants with education acquired abroad more than it affects natives and immigrants who have acquired their education in Denmark. This fact reveals the partial portability of human capital acquired in migrants' origin countries. Furthermore, immigrants with education acquired in their own country reduce their overeducation level as they increase their effective work experience in Denmark. Thus, they successfully assimilate. As for the returns to years of overeducation, Nielsen (2007) shows that immigrants who have studied abroad have the lowest returns, followed by immigrants with Danish qualifications, and by the native-born population who enjoy the highest returns.

On the other hand, there are some studies that have not found any evidence of a successful assimilation process by immigrants in the host country. Dell'Aringa and Pagani (2011) show that the "catch-up" by foreigners in Italy seems unachievable, even once they have adapted their skills to the host country's labour market. Comparing data from 25 countries, the OECD (2007) obtains similar results in most of the countries. Aleksynska and Tritah (2013) reach a similar conclusion in analysing data from the European Social Survey for 22 European countries for the 2002 to 2009 period.

Most of these papers consider vertical mismatch, but there are other indicators of educational mismatch that have not been used until now in the analysis of immigrants. In this paper, we consider horizontal mismatch as another form of educational mismatch.

\section{DATA SOURCES AND DEFINITION OF VARIABLES}

\subsection{Adult Education Survey}

We use microdata provided by Eurostat from the Adult Education Survey (AES), a household survey carried out between 2005 and 2008 in 29 countries that are EU Member States, candidate countries, or countries of the European Free Trade Area. The survey was addressed to individuals between 25 and 64 years old, and its main objective was to study lifelong learning, i.e., those training and learning activities that the adult population performs with the objective of improving or extending knowledge, skills, and competences from a personal, civil, social, or work-related perspective, although it also collects additional information both at the individual and household level. This pilot exercise was set up within a 
common EU framework, including a standard questionnaire, tools, and quality reporting. This database is particularly appropriate for our analysis, because as far as we know, it is the only one that allows for homogenous measurement of both vertical and horizontal mismatch for a wide set of EU countries and for comparisons between immigrant (from EU countries and from non-EU countries) and native workers.

As we focus our interest on immigrants living in EU countries, we only consider those countries in which immigration is a relevant phenomenon (more than $4 \%$ of total population). Thus, as shown in Figure 1, we do not consider Bulgaria, Poland, Romania, and Slovakia. We also have excluded from the analysis Hungary and the Netherlands, because the immigrant population reported in the Adult Education Survey is underrepresented compared with aggregate data from Eurostat ${ }^{7}$. We also exclude Finland, Italy, and the United Kingdom from the analysis, because relevant information for our analysis is missing in their national surveys (in particular, immigrants' years of residence in the host country). After these restrictions, we consider the following 15 EU countries: Austria, Belgium, Cyprus, Czech Republic, Germany, Denmark, Estonia, Spain, France, Greece, Latvia, Lithuania, Portugal, Sweden, and Slovenia.

We restrict our analysis to men and women employed (excluding armed forces employees) at the time of the survey with reliable information about their occupation and level and field of education. We exclude from the analysis individuals below the ISCED 3 education level, since the variable "field of education" is only defined for individuals with education levels higher than ISCED 2. The final sample consists of 30,149 native born workers and 2,699 immigrant workers, of which 929 come from EU countries and 1,770 come from non-EU countries.

FIGURE 1

The variables used in the analysis are related to personal and job characteristics. For personal characteristics, we use information related to the country of residence, gender, age, level of education (ISCED 3, ISCED 4, and ISCED $5 \& 6$ ), type or field of education (8

\footnotetext{
7 Immigrant population in AES is $4.8 \%$ in the Netherlands and $1.6 \%$ in Hungary, while these percentages correspond to $11.1 \%$ and $4.3 \%$, respectively, according to Eurostat data.
} 
categories $\left.^{8}\right)$, and whether workers have taken up any non-formal education activity during the last 12 months. The immigrant condition is defined according to the country of birth, differentiating also between immigrants from EU and non-EU countries. We also consider their years of residence in the host country. For job characteristics, we consider information about the tenure in the firm where they are currently employed, the economic activity of the firm ( 5 categories $\left.^{9}\right)$, and the firm size (10 workers or fewer and more than 10 workers). Finally, we consider dummy variables related to the urban size of the region of residence. Descriptive statistics for these variables are shown in Table A.1 of the Annex.

\subsection{Measuring educational mismatches}

\section{Measuring overeducation}

Three different methods have been proposed to measure vertical skill mismatch: objective, subjective, and statistical (in terms of the mean and the mode). Each procedure has advantages and weaknesses. ${ }^{10}$ As a consequence, the method used generally depends on the nature of the available data.

The objective method is based on "dictionaries" of jobs compiled by job analysts who determine what level and type of education workers should have in order to perform a certain job. A person is deemed overeducated if his/her level of education is higher than the level the analysts define as ideal for the occupation. The subjective method takes into account the perception of the workers to determine the educational mismatch. Finally, the version of the statistical method based on the mean (Verdugo and Verdugo, 1989) considers workers to be overeducated if they have more years of education than the mean of the years of education (plus one standard deviation) of the workers in that occupation. Nevertheless, Kiker et al. (1997) propose the use of the mode instead of the mean; they consider overeducated persons as those who have more years of education than the mode of years of education in the job they perform.

\footnotetext{
8 Education: Teacher training and education science / Humanities: Humanities, languages and arts; Foreign languages / Social Science: Social Science, business and law / Science: Science, mathematics and computing / Engineering: Engineering, manufacturing and construction. / Agriculture: Agriculture and veterinary. / Health: Health and welfare. / Services: Services.

9 The categories of NACE's classification included in each economic sector are the following: agriculture: $A, B$; industry: C, D, E; construction: F; market services: G, H, I, J, K, P, Q; and non-market services: L, M, N, O.

${ }^{10}$ For a discussion, see Hartog (2000).
} 
In this research, we cannot use the objective method because, unfortunately, this kind of indicator is not available for most countries as massive efforts are needed to build occupational dictionaries, which can easily become obsolete due to technical and occupational change; neither can we use the subjective method, because the Adult Education Survey does not provide this information. So, we measure vertical mismatch using the statistical method based on the mode. The Adult Education Survey provides the required information on occupations and educational levels. It is worth mentioning that as we are working with immigrants from countries characterised by heterogeneous educational systems, we measure vertical mismatches considering the level of education instead of the years of schooling, which could vary among countries for the same educational level. With this way of proceeding, we expect to minimise potential measurement errors that can derive from the comparison of very heterogeneous educational systems. Summarising, we consider that workers have vertical mismatch (overeducation) if their level of education is higher than the mode of the native workers' level of education within each occupation.

\section{Measuring horizontal mismatch}

As the analysis of horizontal mismatch is quite recent, most studies have applied similar methods to those used to analyse vertical mismatch. In particular, they use similar approaches but substitute the variable "level of education" with the variable "field of education". In this sense, we also measure horizontal mismatch using the statistical method in terms of the mode for the same reasons explained before. The database provides information about the worker's field of education and occupation. Workers are deemed to have horizontal mismatches if their field or type of education differs from the mode of the native workers' field of education within each occupation.

\section{DESCRIPTIVE EVIDENCE}

In this section, we carry out a descriptive analysis of the differences between natives and immigrants regarding horizontal and vertical mismatches. The percentage of natives, immigrants from EU countries, and immigrants from non-EU countries who show vertical and horizontal mismatch are displayed in Figures 2 and 3 respectively. Interesting insights can be derived from these figures. First, the percentages of horizontal mismatch are higher than the 
percentages of vertical mismatch in all groups (39-46 versus 24-35 respectively). Second, Figure 2 shows that $24 \%$ of natives are overeducated, whereas this percentage is $31 \%$ for immigrants from EU countries and 35\% for immigrants coming from other countries. Nevertheless, in Figure 3 we can see that the percentage of horizontal mismatch for natives and immigrants from EU countries is around $40 \%$ for both groups whilst for immigrants from countries outside the EU is higher at $46 \%$. Although the incidence of horizontal mismatch is higher than the incidence of vertical mismatch for all groups, we observe more differences between natives and immigrants in the incidence of vertical mismatch.

FIGURES 2 and 3

Focusing only on the immigrant population, we see some interesting differences depending on the years of residence in the host country. Figures 4 and 5 show, respectively, the percentage of immigrant workers with vertical and horizontal mismatch by years of residence in the host country. In Figure 5 we see that the incidence of horizontal mismatch decreases for both groups of immigrants as their years of residence increase. This result can be interpreted as evidence of immigrant assimilation. However, the outcomes are different in relation to vertical mismatch (Figure 4). In fact, while for non-EU immigrants the incidence of overeducation also decreases as the years of residence of these immigrants increase, the same is not valid for immigrants from EU countries. In particular, immigrants who reside for fewer than 2 years in the host country present a lower percentage of overeducation than immigrants who reside in the host country between 3 and 5 years. In this case, it seems that the assimilation process in the first 5 years in the host country is not as clear for immigrants from EU countries as for the others. Indeed, Piracha and Vadean (2013) point out that immigrants have initial costs derived from learning a new labour market structure while job seeking from outside the host country or within the host country soon after immigration. In the initial stages following arrival in the new country it is more likely that immigrants end up in jobs that do not require their level of education. While they are working in such jobs, they often continue to search for a better-suited job. However, that explanation is not valid to explain the incidence of overeducation between immigrants from EU countries. In this case, a possible explanation of the unusual finding could be that immigrants leave their first job to accept another one for which they are also overeducated but that provides better job conditions or wages. 
FIGURES 4 and 5

The descriptive analysis carried out in this section does not consider the effect of the characteristics of the individuals on the differences in overeducation and horizontal mismatch. This aspect is considered in the following section.

\section{METHODOLOGY AND RESULTS}

\subsection{Methodology}

In order to know whether there are differences in the probability of being overeducated and the probability of a horizontal mismatch between natives and immigrants after controlling for observable characteristics, we estimate the following biprobit model:

$$
\begin{aligned}
& \operatorname{prob}\left(V_{-} M I S M\right)=\Phi(X \beta) \\
& \operatorname{prob}\left(H_{-} M I S M\right)=\Phi(X \beta)
\end{aligned}
$$

where prob(V_MISM) and prob(H_MISM) denote the probability of being overeducated and the probability of having horizontal mismatch respectively, $\Phi$ is the standard normal cumulative distribution function, $X$ represents the set of observable characteristics, and $\beta$ is the coefficients' vector. As the probability of a particular individual being overeducated depends on a set of explanatory variables similar to horizontal mismatch ${ }^{11}$, the model is estimated by maximum likelihood methods, assuming that the errors in (1) and (2) could be correlated ( $\rho$ being the value of the correlation coefficient) and have a joint bivariate normal probability distribution.

11 The Pearson chi-squared statistics between being overeducated and having horizontal mismatch is 135.22 , a value that allows us to reject the null hypothesis of no association at the usual significance level. 
The explanatory variables are divided into two groups. The first group is related to the personal characteristics of individuals such as gender, age, immigrant condition (also by distinguishing immigrants from EU countries and from non-EU countries), years of residence in the host country, level of education, type or field of education, and whether the workers have undertaken any non-formal education activity in the last 12 months. As we focus our interest on immigrants and their process of assimilation, we also include interactions between the variables related to their different origins (EU and non-EU countries) and their years of residence. The second group of characteristics is related to job characteristics such as tenure in the firm where they are currently employed (in years), economic activity of the firm, and firm size. We also include country fixed-effects and controls for urban size.

To decompose the differences in the probability of vertical (horizontal) mismatch between immigrants and natives, we then apply Yun's (2004) methodology that is composed of two steps. The first consists of estimating equation (1) separately for immigrants and natives: ${ }^{12}$

$$
\begin{gathered}
\operatorname{prob}\left(V_{-} M I S M\right)_{I}=\Phi\left(X_{I} \beta_{I}\right) \\
\operatorname{prob}\left(V_{-} M I S M\right)_{N}=\Phi\left(X_{N} \beta_{N}\right)
\end{gathered}
$$

The second step consists of decomposing the mean difference between immigrants (I) and natives $(\mathrm{N})$ in the probability of having vertical (horizontal) mismatch as:

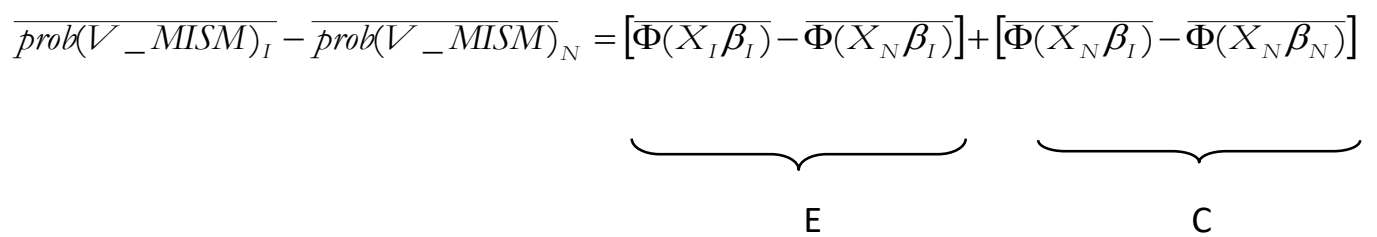

The component labelled $E$ refers to the part of the difference in the probability of a vertical (horizontal) mismatch between immigrants and natives due to differences in

\footnotetext{
12 It is worth mentioning that in this kind of analysis it is impossible to include information on the years of residence,
} as natives do not share this characteristic. 
observable characteristics. For instance, whether immigrants are more likely to be overeducated than natives because they are younger or working in smaller companies (in the mean) than natives. On the other hand, the $C$ component refers to the part of this difference due to differences in coefficients-i.e., natives and immigrants of the same age could have different probabilities of being overeducated. The method also proposes a detailed decomposition that allows understanding the unique contribution of each predictor to each component of the difference. Oaxaca and Ransom (1999) propose a normalisation procedure to account for the fact that the detailed Oaxaca (1973) decomposition is not invariant to the choice of the reference category when sets of dummy variables are used. Particularly, if a model includes dummy variables, then the sum of the detailed coefficients effects attributed to the dummy variables is neither invariant to the choice of the reference category nor to the omitted category. Yun (2005) applies the normalisation procedure in logistic regression-a correction that is also used here.

\subsection{Results}

The marginal effects of the probability of being overeducated (vertical mismatch) and having horizontal mismatch that have been estimated from a biprobit model are shown in Table 1. Models (1) and (2) only include some personal characteristics as explanatory variables, while in model (3) additional controls have been added.

Regarding overeducation, results from the left column of model (1) clearly show that immigrants are more likely to be overeducated than natives after controlling for some personal observable characteristics (the difference is of 32.5 percentage points). However, the negative sign of the variable years of residence indicates that the fewer the number of years lived in the host country, the lower the probability of being overeducated. For each additional year of residence in the host country the probability of being overeducated is reduced by 2.5 percentage points. There seems to be an assimilation process in the host country in terms of overeducation. However, language knowledge does not seem to influence the probability of being overeducated. In model (2) we introduce two dummies for immigrants in order to distinguish between immigrants coming from EU countries and immigrants coming from nonEU countries. We can see that immigrants from non-EU countries are more likely to be overeducated than immigrants from EU countries. Concerning the process of assimilation of both types of immigrants, the results for the interactions between years of residence and immigrant dummies show that an additional year of residence reduces the probability of 
overeducation among non-EU immigrants more than for those from EU countries. In particular, the probability of an EU immigrant being overeducated is reduced by 2 percentage points for each year of residence in the host country; this reduction is equal to 2.8 percentage points for immigrants from countries outside EU. Therefore, although immigrants from countries outside the EU have a higher probability of being overeducated, their process of assimilation is faster than that of immigrants from EU countries. These differences between groups hold when additional personal and job controls are included in model (3), although as more controls are added the coefficients are slightly reduced. The inclusion of additional control variables does not change the main results of the variables related to immigrants.

Regarding horizontal mismatch, the right column of model (1) shows that the probability of having a horizontal mismatch is 17 percentage points higher for immigrants than for natives. It is also worth noting that the difference in the probability of horizontal mismatch between immigrants and natives is much lower than the difference in the probability of overeducation (which is equal to 32.5 percentage points). Regarding the years of residence in the host country, we can see that the probability of horizontal mismatch is only reduced by 1.2 percentage point for each additional year, and this effect is also not statistically significant. Results from model (2) show that immigrants from non-EU countries are more likely to have horizontal mismatch than natives (18.7 percentage points of difference). On the other hand, the difference in the probability of horizontal mismatch between natives and immigrants from EU countries is not significant. Moreover, the interactions between years of residence and both types of immigrants are not significant. When additional variables are included in model (3), the higher probability of horizontal mismatch of immigrants from non-EU countries is slightly reduced (14.8 percentage points) but remains statistically significant at the $10 \%$ significance level. It is worth mentioning that in the three models the parameter capturing the correlation between the error terms of the two models is statistically significant at the usual levels.

TABLE 1

Once the differences between natives and immigrants in the probability of overeducation and horizontal mismatch are detected, we apply the Yun decomposition (Yun, 2004) method to try to explain them. Given that there are no statistically significant differences in the probability of horizontal mismatch between EU immigrants and natives, we do not decompose this difference. 
This decomposition helps us identify the factors influencing the differences in the probability of being overeducated (or horizontally mismatched) between immigrants and natives. In particular, the method allows us to detect whether the differences in the probability of being overeducated (horizontally mismatched) between natives and immigrants are due to differences in the observable characteristics (endowment of human capital or job characteristics) or to differences in the effect or contribution of these characteristics between the two groups. Table 2 shows the aggregated results of Yun's (2004) decomposition. ${ }^{13}$ From this table we can see that the total difference in the probability of being overeducated between both types of immigrants and natives is statistically significant and consistent with the differences in the percentages of overeducation between groups observed in Figure 2. The same consistency can be observed for the difference in the percentages of horizontal mismatch between immigrants from non-EU countries and natives and those observed in Figure 3. In particular, we find that the difference in the probability of overeducation is 7 percentage points for immigrants from EU countries and 11 percentage points when immigrants from non-EU countries are compared to natives. On the other hand, the horizontal mismatch's probability difference between non-EU countries and natives is 7 percentage points. In both vertical and horizontal mismatch, immigrants experience a higher probability of being mismatched, but the causes of these differences differ between groups. In fact, in the case of the difference in the probability of being overeducated between immigrants from EU countries and natives, we can see that $52 \%$ of this difference is explained by differences in characteristics. Immigrants from EU countries have a higher probability of being overeducated, partly because they have more observable characteristics that contribute to overeducation over natives. Also, $48 \%$ of this difference is due to differences in coefficients, even if the component is statistically significant only at the $10 \%$ level. Therefore, immigrants from the EU and natives have a higher probability of being overeducated, because they see differences in the effects of those characteristics. ${ }^{14}$ Concerning the difference in the probability of being overeducated between immigrants from non-EU countries and natives, $87 \%$ of this difference can be explained by differences in coefficients (and it is statistically significant). On the other hand, differences in characteristics do not play an important role. The detailed decomposition shows that the age of immigrants is very important in explaining this difference. In fact, age can be an indicator of human capital, as can job experience acquired in the home country; this

\footnotetext{
13 The results of the detailed decomposition are shown in Table A.2. in the Annex.

${ }^{14}$ Detailed Yun decomposition presented in Table A.2. shows that each observed variable is significant to explain this difference.
} 
kind of human capital would be valued less for immigrants than for natives. This may indicate a limited transferability of their human capital to the host country.

Finally, differences in the probability of horizontal mismatch between immigrants from non-EU countries and natives are due to differences in coefficients (90\%). Detailed decomposition results show that this difference is highly related to the immigrants' field of education. Immigrants who have studied the humanities or education studies have more difficulty finding work in their field than similar natives. This result may also be explained by a limited transferability of human capital acquired in the home country, as shown by AdamutiTrache et al. (2013).

TABLE 2

\section{FINAL REMARKS}

In this paper we have analysed the incidence of different types of educational mismatches (vertical and horizontal) among native and immigrant workers using microdata from the Adult Education Survey (AES). We have also tried to explain the differences in the probability of educational mismatches between natives and immigrants.

Our results show that immigrants are more likely to be overeducated than natives, and that this effect is higher for immigrants from non-EU countries than for those from other EU countries, although the probability of being overeducated decreases more quickly with years of residence for non-EU immigrants. On the other hand, we do not find striking evidence in the case of horizontal mismatch. In particular, results show that only immigrants from non-EU countries have a higher probability of horizontal mismatch than natives. However, this effect does not vary when years of residence in the host country increase.

Applying Yun's (2004) decomposition, we also find that immigrants from the EU have a higher probability of being overeducated than natives, because they are characterised by both higher accumulation of observable characteristics, which increase the probability of overeducation, and by a lower return to the these characteristics, whereas results for immigrants from non-EU countries (also for horizontal mismatch) suggest that the gap is almost entirely explained by differences in the effects of observable characteristics. This result 
points out that especially immigrants from non-EU countries may have a limited transferability of human capital, which results in their situation of overeducation and horizontal mismatch in the host country.

To sum up, our results confirm that immigrants experience a higher overeducation incidence than natives due to the imperfect transferability of the human capital acquired in their origin countries. However, immigrants accumulate knowledge and experience in the host country that help them adapt to the local labour market, thus facilitating an assimilation process that reduces the intensity of overeducation. However, the pace of assimilation is notably slow for all immigrants. There is a certain risk that immigrants from outside the EU will remain permanently trapped in bad jobs, regardless of their levels of education. Taking into account the wage consequences of overeducation, this last result implies that the wage gap between native and immigrants will not disappear after several years of residence in the host country.

If the ENP really wants to improve the mobility of qualified workers from neighbouring countries to the EU, policy actions should focus on three areas: first, incorporating in migration policy formal criteria related to educational levels, with a view to matching current needs in the labour market (e.g., the Australian points system); second, trying to design a system of assessment and recognition of foreign-acquired educational degrees in order to give an appropriate signal to the labour market and facilitate a better match between immigrants and available jobs in the home country-an aspect that could be easily handled within the bilateral action plans that have characterised the ENP since its creation; and third, providing publiclyprovided informal training to recently arrived immigrants with appropriate skills in order to improve the transferability of their skills to the new labour market. 


\section{ACKNOWLEDGMENTS}

The research leading to these results has received funding from the European Community's Seventh Framework Programme (FP7/2010-2.2-1) under grant agreement no 266834. We make use of microdata from the European Commission, Eurostat, AES 2007 database made available by Eurostat under contract AES/2012/06. Eurostat has no responsibility for the results and conclusions reported here.

\section{REFERENCES}

Adamuti-Trache, M., Anisef, P., Sweet, R. (2013), "Impact of Canadian postsecondary education on occupational prestige of highly educated immigrants", Canadian Review of Sociology, vol. 50 (2), pp. 178-202.

Akresh, I. R. (2008), "Occupational trajectories of legal US immigrants: Downgrading and recovery", Population and Development Review, vol. 34(3), pp. 435-456.

Aleksynska, M. and Tritah, A. (2013), "Occupation-Education Mismatch of Immigrant Workers in Europe: Context and Policies", Economics of Education Review, 36, pp. 229-244.

Baker, M. and Benjamin, D. (1994), "The Performance of Immigrants in the Canadian Labor Market", Journal of Labor Economics, vol. 12(3), pp. 369-405.

Bell, B. (1997), "The Performance of Immigrants in the United Kingdom: Evidence from the GHS". Economic Journal, vol. 107(441), pp. 333-344.

Card, D. (1999), "Causal Effect of Education on Earnings", in Ashenfelter O, Card D (dir.), Handbook of Labor Economics, vol. 3, Elsevier Science: Amsterdam; 1801-1863.

Carneiro, A., Fortuna, N., Varejão, J. (2012), "Immigrants at new destinations: How they fare and why", Journal of Population Economics, vol. 25(3), pp. 1165-1185.

Chiswick, B. R. (1978), "The Effect of Americanization on the Earnings of Foreign-born Men", Journal of Political Economy, vol. 86(5), pp. 897-921.

Chiswick, B. R. and Miller, P. (1985), "Immigrant Generation and Income in Australia", Economic Record, vol. 61(173), pp. 540-553.

Chiswick, B. R. and Miller, P. (1995), "The endogeneity between language and earnings: an international analysis", Journal of Labor Economics, vol. 13(2), pp. 246-288.

Chiswick, B. R. and Miller, P. (2007), "The International Transferability of Immigrants' Human Capital Skills", IZA Discussion paper n. 2670, March 2007, 27 p. 
Chiswick, B. and Miller, P. (2008), "Why is the payoff to schooling smaller for immigrants?", Labour Economics, vol. 15, pp. 1317-1340.

Chiswick, B. and Miller, P. (2009), "The International Transferability of Immigrants' Human Capital Skills", Economics of Education Review, vol. 28 (2), pp. 162-169.

Chiswick, B. and Miller, P. (2010), "The Effects of Educational-Occupational Mismatch on Immigrant Earnings in Australia, with International Comparisons", International Migration Review, vol. 44(4), pp. 869-898.

Constant, A. and Massey, D. (2003), "Self-selection, earnings, and out-migration: A longitudinal study of immigrants to Germany", Journal of Population Economics, vol. 16, pp. 631-653.

Danzer, A. M., Dietz, B. (2014), "Labour Migration from Eastern Europe and the EU's Quest for Talents”, Journal of Common Market Studies, vol. 52(2), pp. 183-199.

Dell'Aringa C. and Pagani, L. (2011), "Labour Market Assimilation and Over-Education: The Case of Immigrant Workers in Italy", Economia Politica, 2, pp. 219-240.

Duleep, H. and Regets, M. (1997), "The Decline in Immigrant Entry Earnings: Less Transferable Skills or Lower Ability?" The Quarterly Review of Economics and Finance, vol. 37, Special Issue, pp. 189-208.

Duncan, G. and Hoffman, S. (1981), "The Economic Value of Surplus Education", Economics of Education Review vol. 1 (1), pp. 75-86.

Dustman, C. and Glitz, A. (2011), "Migration and Education", in Handbook of the Economics of Education, vol. 4, pp. 327-439.

Freeman, R. B. (1976), "The Overeducated American", London: Academic Press.

Friedberg, R. (2000), “You Can't Take It with You? Immigrant Assimilation and the Portability of Human Capital", Journal of Labor Economics, vol. 18, n. 2, pp. 221-251.

Green, C., Kler, P. and Leeves, G. (2007), "Immigrant overeducation: Evidence from recent arrivals to Australia", Economics of Education Review, 26, pp. 420-432.

Hartog, J. (2000), "Over-education and earnings: where are we, where should we go?", Economics of Education Review, vol. 19, pp. 131-147.

Kiker, B.F., Santos, M.C. and Mendes de Oliveira, M. (1997), "Overeducation and Undereducation: Evidence for Portugal", Economics of Education Review, vol. 16 (2), pp. 111-125.

Kler, P. (2006), "Overeducation among tertiary educated immigrants to Australia: A longitudinal study", Labour Economics Research Group, University of Queensland, Discussion Paper n. 9, January 2006, 39 p.

Leuven, E. and Oosterbeek, H. (2011), "Overeducation and Mismatch in the Labor Market in Handbook of the Economics of Education", vol. 4, pp. 283-326. 
Lindley, J. and Lenton, P. (2006). The Overeducation of UK Immigrants: Evidence from the Labour Force Survey, Sheffield Economic Research Paper Series n. 2006001, 20 p.

Longva, P. and Raaum, O. (2003), "Earnings assimilation of immigrants in Norway - A reappraisal”, Journal of Population Economics, vol. 16, pp. 177-193.

Mcguinness, S. (2006), "Overeducation in the labour market", Journal of Economic Surveys, Vol. 20 (3), pp. 387-418.

Nielsen, Ch. P. (2007), "Immigrant Overeducation: Evidence from Denmark”, World Bank Policy Research Working Paper 4234, May 2007, 54 p.

Nordin, M., Persson, I., Rooth, D. (2010), "Education-occupation mismatch: Is there an income penalty?", Economics of Education Review, vol. 29 (6), pp. 1047-1059.

Oaxaca, R. (1973), "Male-Female Wage Differentials in Urban Labor Markets", International Economic Review, vol. 14 (3), pp. 139-148.

Oaxaca, R. L. and Ransom, M. R. (1999), "Identification in Detailed Wage Decompositions", The Review of Economics and Statistics, vol. 81 (1), pp. 154-157.

OECD (2007), International Migration Outlook, Annual Report 2007. OECD, Paris.

Piracha, M. and Vadean, F (2013), "Migrant Educational Mismatch and the Labour Market" in Amelie F. Constant and Klaus F. Zimmermann (eds.), International Handbook on the Economics of Migration, Edward Elgar, pp. 176-192.

Poot, J. and Stillman, S. (2010), "The Importance of Heterogeneity When Examining Immigrant Education-Occupation Mismatch: Evidence from New Zealand”, IZA DP 5211.

Psacharopoulos, G. and Patrinos, H. A. (2004), "Returns to investment in education: A further update", Education Economics, vol. 12(2), pp. 111-134.

Robst, J. (2007), "Education and job match: The relatedness of college major and work", Economics of Education Review, vol. 26(4), pp. 397-407.

Robst, J. (2008), "Overeducation and college major: expanding the definition of mismatch between schooling and jobs", The Manchester School, vol. 76(4), pp. 349-468.

Rumberger, R. (1981), “Overeducation in the US Labor Market”, Praeger, New York.

Rubb, S. (2003), "Overeducation in the labor market: A comment and re-analysis of a metaanalysis", Economics of Education Review, vol. 22 (6), pp. 621-629.

Sanromá, E., Ramos, R. and Simón, H. (2008), "The Portability of Human Capital and Immigrant Assimilation: Evidence for Spain”, IZA Discussion Paper No. 3649

Schmidt, C. (1992), "Country of origin differences in the earnings of German immigrants", Discussion Paper 92-29, University of Munich. 
Shields, M. and Wheatley Price, S. (1998), "The earnings of male immigrants in England: evidence from the quarterly LFS", Applied Economics, vol. 30, pp. 1157-1168.

Verdugo, R. and Verdugo, N. (1989), "The impact of surplus schooling on earnings", Journal of Human Resources, vol. 24 (4), pp. 629-643.

Wolbers, M. (2003), "Job Mismatches and their Labour-Market Effects among School-Leavers in Europe", European Sociological Review, vol. 19 (3), pp. 249-266.

Yun, M. (2004), "Decomposing differences in the first moment", Economics Letters, vol. 82(2), pp. $275-280$.

Yun, M. (2005), "A simple solution to the identification problem in detailed wage decompositions", Economic Inquiry, 43, pp. 766-772. 
Figure 1. Proportion of immigrant' population in total population (average 2009-2011)

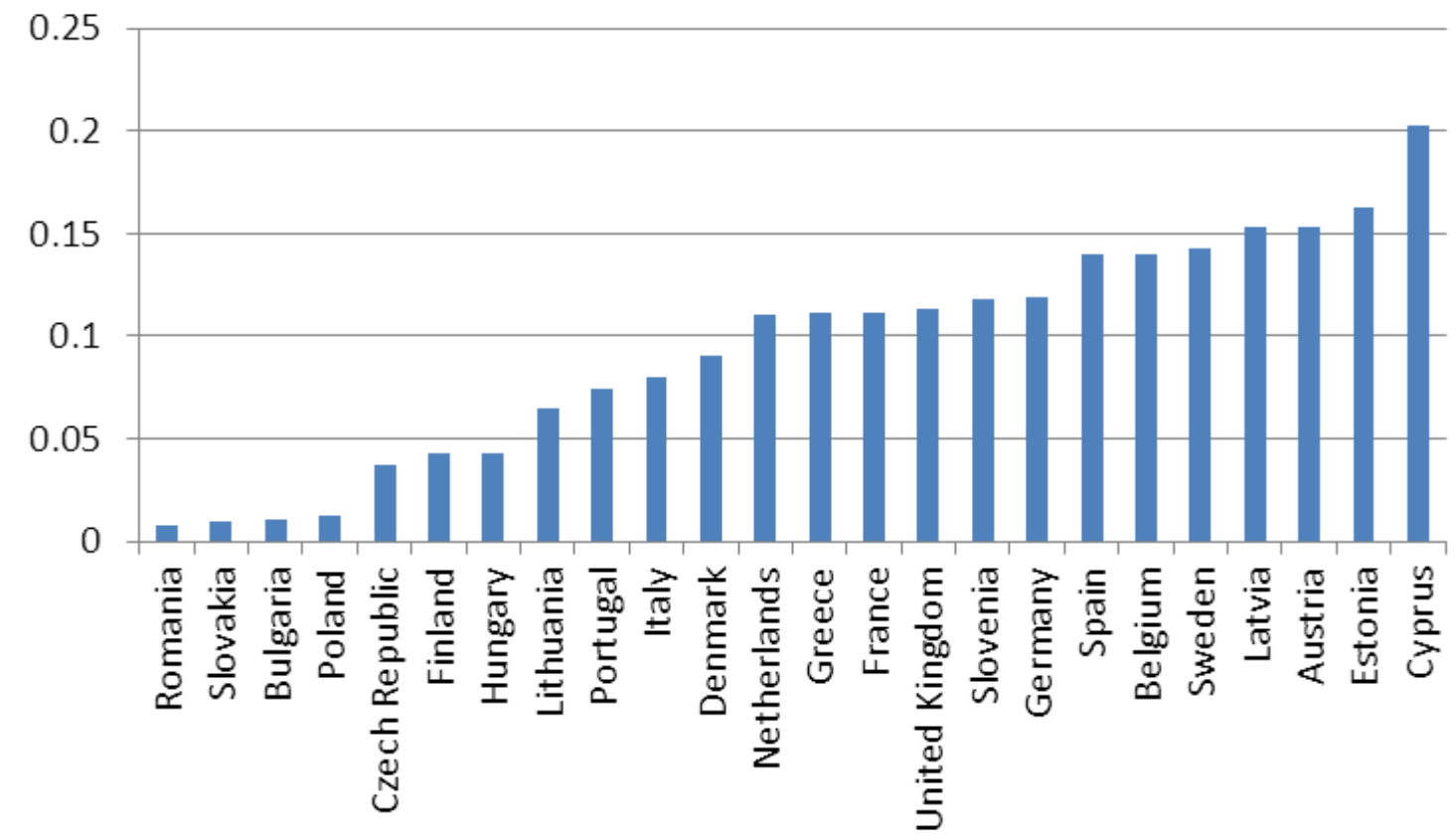

Source: Eurostat. The proportion is computed as the division of the number of immigrant population and total of population in each country.

Figure 2. Incidence of overeducation

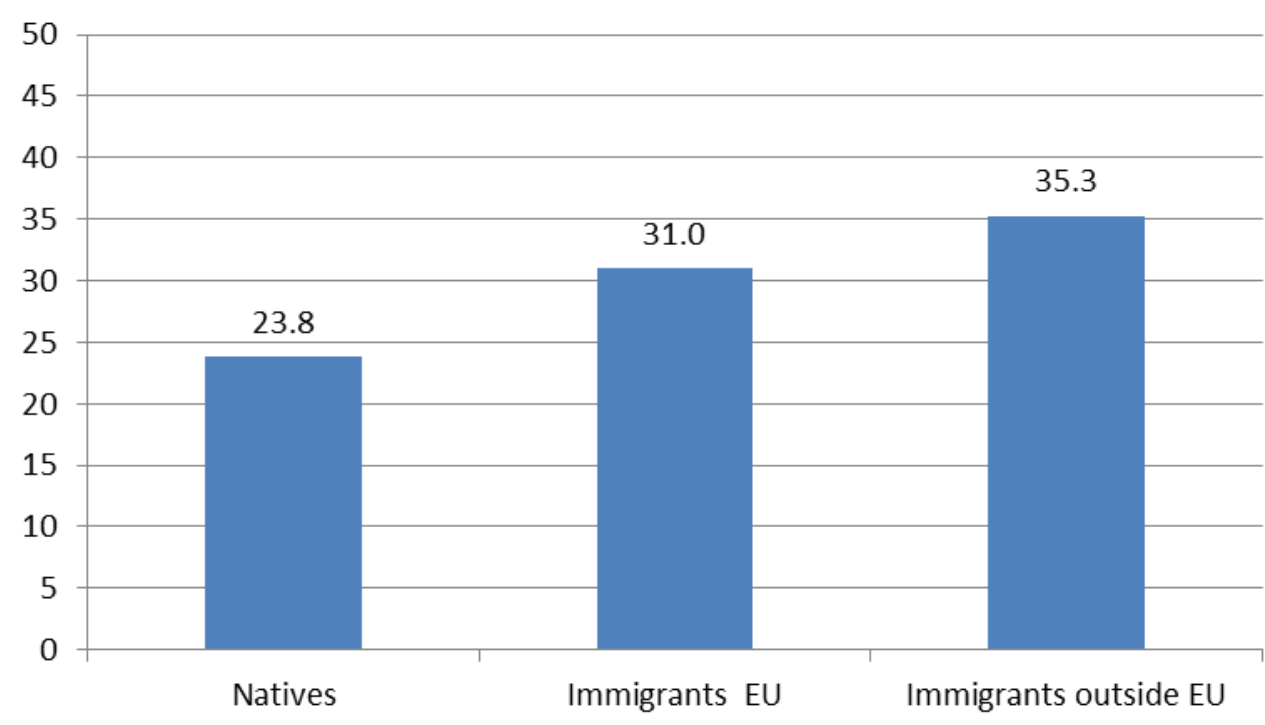

Data: AES 2007. Proportion of workers with a level of education higher than the mode of the workers' level of education within each occupation. 
Figure 3. Incidence of horizontal mismatch

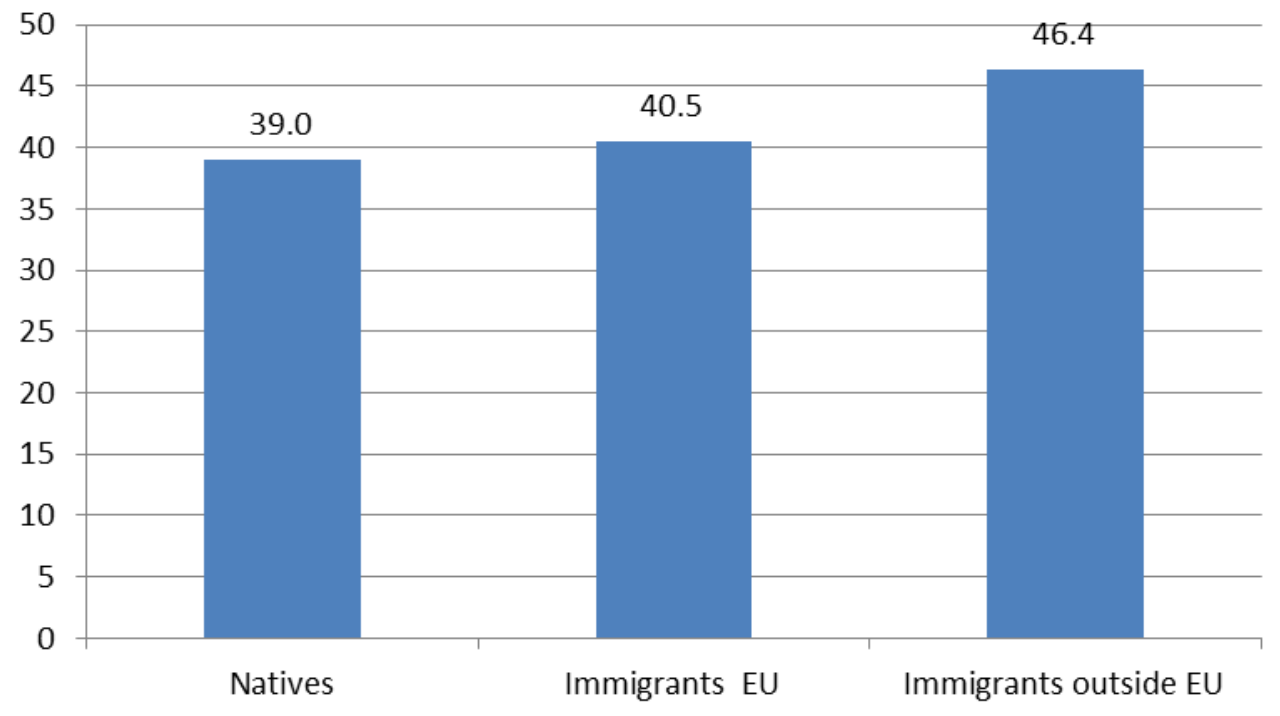

Data: AES 2007. Proportion of workers with a field or type of education different from the mode of the workers' field of education within each occupation.

Figure 4. Incidence of vertical mismatch across immigrants by years of residence in the host country

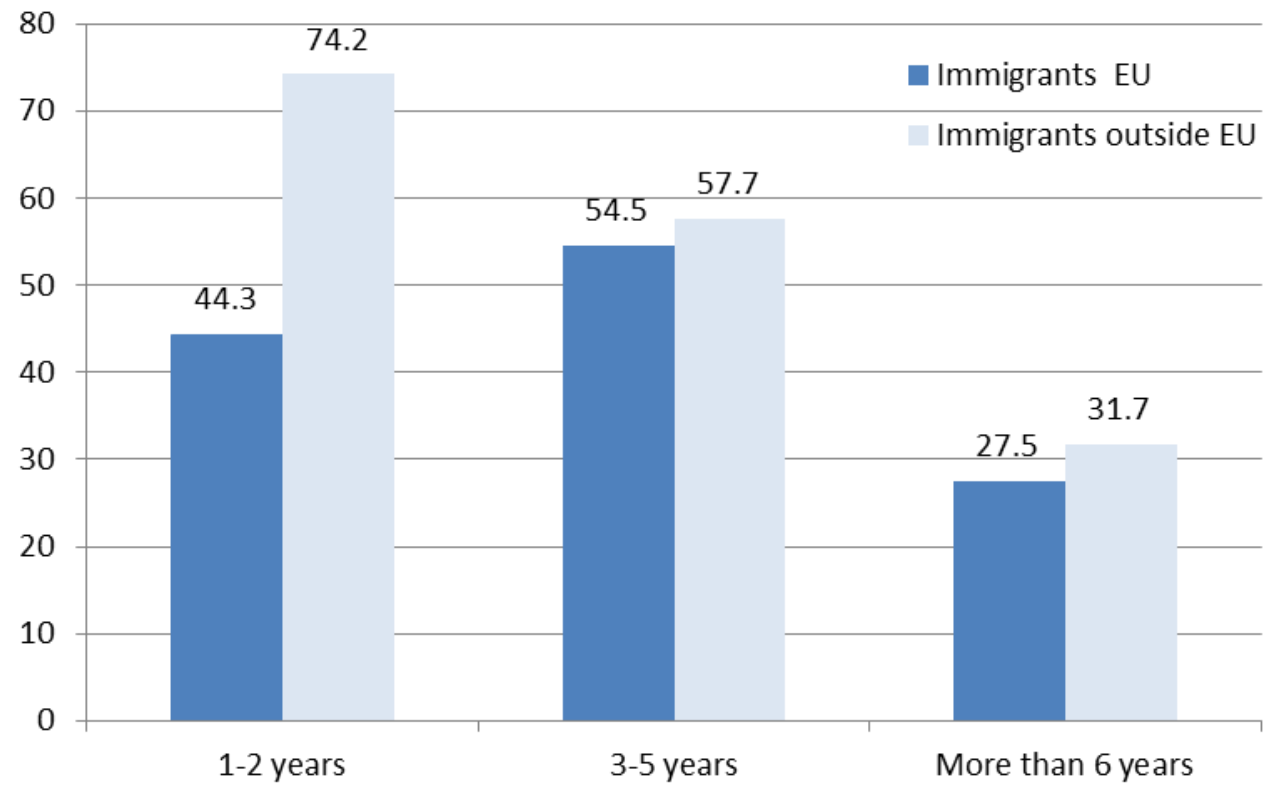

Data: AES 2007 
Figure 5. Incidence of horizontal mismatch across immigrants by years of residence in the host country

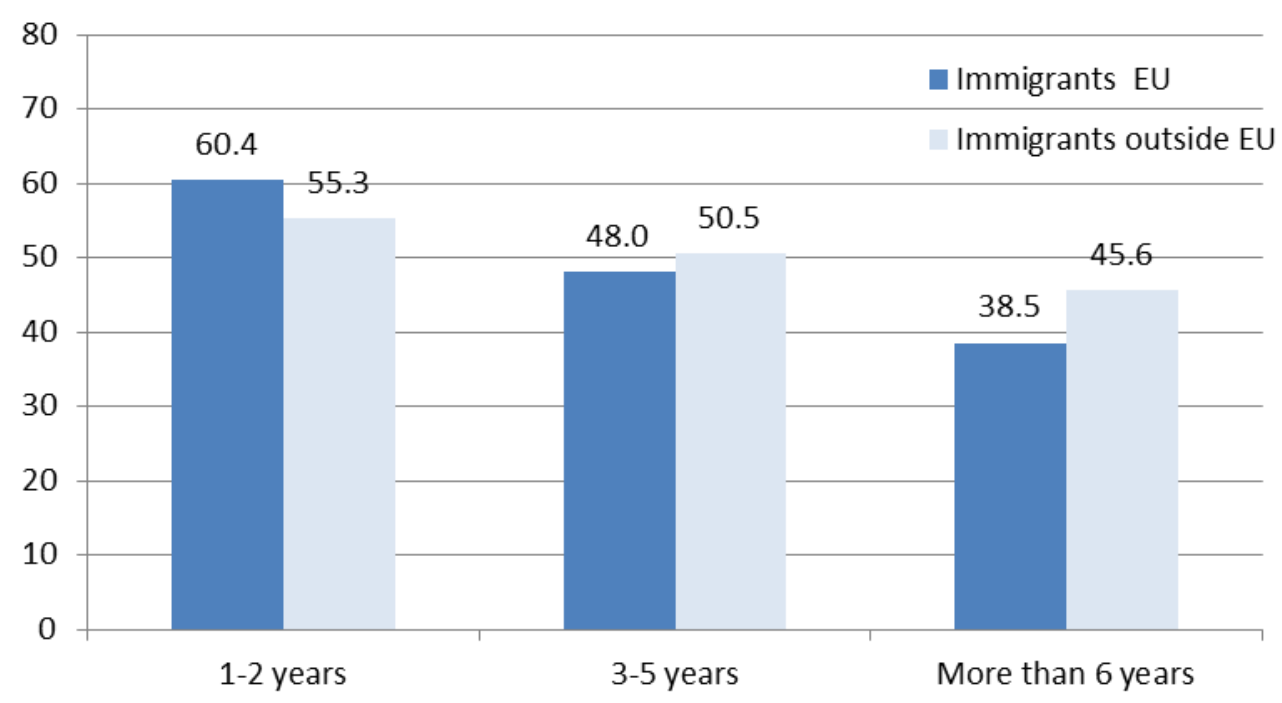

Data: AES 2007 
Table 1: Determinants of overeducation and horizontal mismatch

\begin{tabular}{|c|c|c|c|c|c|c|}
\hline \multirow[t]{2}{*}{ Biprobit marginal effects } & \multicolumn{2}{|c|}{ (1) } & \multicolumn{2}{|c|}{ (2) } & \multicolumn{2}{|c|}{ (3) } \\
\hline & Overed. & H. mismatch & Overed. & H. mismatch & Overed. & H. mismatch \\
\hline \multirow[t]{2}{*}{ Immigrant } & $0.325 * * *$ & $0.171^{* *}$ & & & & \\
\hline & {$[0.0540]$} & {$[0.0772]$} & & & & \\
\hline \multirow[t]{2}{*}{ Immig. EU } & & & $0.259 * * *$ & 0.141 & $0.223 * * *$ & 0.0429 \\
\hline & & & {$[0.0671]$} & [0.0879] & {$[0.0621]$} & {$[0.0625]$} \\
\hline \multirow[t]{2}{*}{ Immig. No-EU } & & & $0.369 * * *$ & $0.187^{* *}$ & $0.336 * * *$ & $0.101^{*}$ \\
\hline & & & [0.0532] & [0.0739] & [0.0463] & [0.0530] \\
\hline \multirow[t]{2}{*}{ Male } & 0.00959 & $-0.0546^{*}$ & 0.00948 & $-0.0548^{*}$ & -0.00678 & -0.0123 \\
\hline & {$[0.0315]$} & [0.0286] & {$[0.0315]$} & {$[0.0286]$} & [0.0188] & [0.0122] \\
\hline \multirow[t]{2}{*}{ Age } & $-0.00377^{*}$ & $0.00105^{* * *}$ & $-0.00376^{*}$ & $0.00106 * * *$ & -0.00183 & $0.00352^{* * *}$ \\
\hline & {$[0.00197]$} & {$[0.000260]$} & {$[0.00197]$} & {$[0.000258]$} & [0.00145] & {$[0.000700]$} \\
\hline \multirow[t]{2}{*}{ Years of residence } & $-0.0246 * * *$ & -0.0121 & & & & \\
\hline & {$[0.00422]$} & {$[0.00888]$} & & & & \\
\hline \multirow[t]{2}{*}{ Years of residence $x$ immig. EU } & & & $-0.0201 * * *$ & -0.013 & $-0.0183^{* * *}$ & -0.00658 \\
\hline & & & {$[0.00586]$} & {$[0.0101]$} & {$[0.00545]$} & {$[0.00537]$} \\
\hline \multirow[t]{2}{*}{ Years of residence $x$ immig. No-EU } & & & $-0.0280 * * *$ & -0.0115 & $-0.0264 * * *$ & -0.00654 \\
\hline & & & {$[0.00367]$} & {$[0.00860]$} & [0.00349] & {$[0.00531]$} \\
\hline \multirow[t]{2}{*}{ Not knowledge of language } & -0.0302 & 0.0268 & -0.0256 & 0.0297 & -0.021 & 0.0648 \\
\hline & [0.0372] & [0.0335] & {$[0.0394]$} & [0.0338] & [0.0420] & {$[0.0396]$} \\
\hline \multirow[t]{2}{*}{ Educational level (ref. ISCED 3) - ISCED 4} & $0.550^{* * *}$ & -0.0082 & $0.550^{* * *}$ & -0.00823 & $0.549 * * *$ & $-0.0302^{* * *}$ \\
\hline & [0.123] & [0.0112] & [0.123] & {$[0.0113]$} & [0.122] & {$[0.0100]$} \\
\hline \multirow[t]{2}{*}{ Educational level (ref. ISCED 3) - ISCED $5 \& 6$} & 0.13 & 0.0177 & 0.131 & 0.0179 & 0.153 & $-0.0322 * *$ \\
\hline & [0.132] & [0.0175] & {$[0.132]$} & [0.0175] & [0.139] & [0.0129] \\
\hline \multirow[t]{2}{*}{ Non formal education } & $-0.0302^{* * *}$ & $0.0222^{*}$ & $-0.0298^{* * *}$ & $0.0229 *$ & -0.0129 & 0.0136 \\
\hline & [0.00984] & [0.0128] & {$[0.00968]$} & [0.0130] & [0.00823] & {$[0.00967]$} \\
\hline \multicolumn{7}{|l|}{ Field of education (ref. Education) } \\
\hline Humanities & & & & & $0.172^{* * *}$ & $0.619 * * *$ \\
\hline & & & & & [0.0304] & {$[0.0590]$} \\
\hline Social science & & & & & $0.136 * * *$ & $-0.149 * * *$ \\
\hline & & & & & {$[0.0278]$} & {$[0.0573]$} \\
\hline Science & & & & & $0.101^{* * *}$ & $0.740 * * *$ \\
\hline & & & & & {$[0.0198]$} & [0.123] \\
\hline Engineering & & & & & $0.127^{* * *}$ & -0.0378 \\
\hline & & & & & {$[0.0382]$} & [0.0245] \\
\hline Agriculture & & & & & $0.174 * * *$ & $0.419 * * *$ \\
\hline & & & & & {$[0.0416]$} & {$[0.0647]$} \\
\hline Health & & & & & $0.106^{* *}$ & 0.042 \\
\hline & & & & & [0.0489] & [0.0295] \\
\hline Services & & & & & $0.175^{* * *}$ & $0.314^{* * *}$ \\
\hline & & & & & [0.0423] & {$[0.0340]$} \\
\hline Economic activity (ref. industry) & & & & & & \\
\hline Agriculture & & & & & -0.0195 & -0.0181 \\
\hline & & & & & [0.0313] & {$[0.0285]$} \\
\hline Construction & & & & & -0.0191 & $-0.160 * * *$ \\
\hline & & & & & {$[0.0371]$} & {$[0.0451]$} \\
\hline Services & & & & & -0.0347 & $0.0571^{* *}$ \\
\hline & & & & & {$[0.0355]$} & {$[0.0236]$} \\
\hline No sale services & & & & & $-0.0913 * *$ & 0.053 \\
\hline & & & & & {$[0.0408]$} & {$[0.0400]$} \\
\hline Tenure & & & & & $-0.00237^{* *}$ & $-0.00439 * * *$ \\
\hline & & & & & [0.000922] & {$[0.00111]$} \\
\hline Firm size (more than 10 workers) & & & & & $-0.0359 * *$ & 0.000626 \\
\hline & & & & & {$[0.0156]$} & [0.00499] \\
\hline Rho (estimated coefficient) & 0.104 & $49 * * *$ & 0.10 & $44^{* * *}$ & 0.12 & $77^{* * *}$ \\
\hline & {$[0.0$} & 318] & {$[0.0$} & 317] & & 309] \\
\hline Observations & $32 \varepsilon$ & 848 & & 848 & & 848 \\
\hline
\end{tabular}


Table 2: General decomposition of the differences in the probability of overeducation and horizontal mismatch between immigrants and natives

\begin{tabular}{|c|c|c|c|}
\hline & \multicolumn{2}{|c|}{ Prob. overeducation } & \multirow{2}{*}{$\begin{array}{c}\text { Prob. Horizontal mismatch } \\
\text { Immigrants from non-EU } \\
\text { vs. Natives }\end{array}$} \\
\hline & $\begin{array}{c}\text { Immigrants from EU } \\
\text { vs. Natives }\end{array}$ & $\begin{array}{c}\text { Immigrants from non-EU } \\
\text { vs. Natives }\end{array}$ & \\
\hline Diff. in characteristics & $\begin{array}{l}0.0364 * * * \\
(52 \%)\end{array}$ & $\begin{array}{c}0.0138 \\
(13 \%)\end{array}$ & $\begin{array}{c}0.00666 \\
(10 \%)\end{array}$ \\
\hline Diff. in coefficients & $\begin{array}{c}0.0342^{*} \\
(48 \%)\end{array}$ & $\begin{array}{l}0.0979 * * * \\
(87 \%)\end{array}$ & $\begin{array}{c}0.0574 * * \\
(90 \%)\end{array}$ \\
\hline Total & $\begin{array}{c}0.0705 * * * \\
(100 \%)\end{array}$ & $\begin{array}{c}0.112^{* * *} \\
(100 \%)\end{array}$ & $\begin{array}{c}0.0641 * * * \\
(100 \%)\end{array}$ \\
\hline
\end{tabular}




\section{Annex}

Table A.1. Weighted descriptive statistics (continues)

\begin{tabular}{|c|c|c|c|c|c|c|}
\hline \multirow[b]{2}{*}{ Variable } & \multicolumn{2}{|c|}{ Natives } & \multicolumn{2}{|c|}{ Immigrant from EU } & \multicolumn{2}{|c|}{ Immigrant from outside EU } \\
\hline & Mean & Std. Dev & Mean & Std. Dev & Mean & Std. Dev \\
\hline Male & 0.517 & 0.500 & 0.577 & 0.494 & 0.604 & 0.489 \\
\hline Female & 0.483 & 0.500 & 0.423 & 0.494 & 0.396 & 0.489 \\
\hline Age & 41.449 & 9.685 & 41.430 & 9.412 & 40.639 & 9.140 \\
\hline Years of residence & ---- & ---- & 9.507 & 2.869 & 9.495 & 2.646 \\
\hline Not knowledge of language & ---- & ---- & 0.042 & 0.200 & 0.036 & 0.186 \\
\hline Education level ISCED 3 & 0.528 & 0.499 & 0.528 & 0.499 & 0.563 & 0.496 \\
\hline Education level ISCED 4 & 0.076 & 0.265 & 0.051 & 0.221 & 0.063 & 0.243 \\
\hline Education level ISCED 5\&6 & 0.395 & 0.489 & 0.420 & 0.494 & 0.374 & 0.484 \\
\hline Non-formal education (NFE) & 0.541 & 0.498 & 0.522 & 0.500 & 0.378 & 0.485 \\
\hline No NFE & 0.459 & 0.498 & 0.478 & 0.500 & 0.622 & 0.485 \\
\hline \multicolumn{7}{|l|}{ Field of education: } \\
\hline Education & 0.057 & 0.232 & 0.037 & 0.189 & 0.033 & 0.180 \\
\hline Humanities & 0.057 & 0.232 & 0.097 & 0.297 & 0.060 & 0.237 \\
\hline Social science & 0.290 & 0.454 & 0.188 & 0.391 & 0.228 & 0.420 \\
\hline Science & 0.052 & 0.223 & 0.059 & 0.236 & 0.074 & 0.262 \\
\hline Engineering & 0.337 & 0.473 & 0.462 & 0.499 & 0.409 & 0.492 \\
\hline Agriculture & 0.026 & 0.160 & 0.018 & 0.132 & 0.024 & 0.153 \\
\hline Health & 0.109 & 0.311 & 0.069 & 0.254 & 0.077 & 0.267 \\
\hline Services & 0.071 & 0.258 & 0.069 & 0.254 & 0.095 & 0.293 \\
\hline \multicolumn{7}{|l|}{ Economic activity: } \\
\hline Agriculture & 0.012 & 0.110 & 0.005 & 0.072 & 0.009 & 0.097 \\
\hline Industry & 0.230 & 0.421 & 0.220 & 0.415 & 0.264 & 0.441 \\
\hline Construction & 0.061 & 0.240 & 0.101 & 0.302 & 0.090 & 0.286 \\
\hline Market services & 0.321 & 0.467 & 0.410 & 0.492 & 0.370 & 0.483 \\
\hline Non-market services & 0.375 & 0.484 & 0.263 & 0.441 & 0.267 & 0.443 \\
\hline Tenure & 12.423 & 10.016 & 9.315 & 8.118 & 7.995 & 7.746 \\
\hline \multicolumn{7}{|l|}{ Firm size: } \\
\hline More than 10 workers & 0.787 & 0.409 & 0.772 & 0.420 & 0.742 & 0.438 \\
\hline 10 workers or less & 0.213 & 0.409 & 0.228 & 0.420 & 0.258 & 0.438 \\
\hline \multicolumn{7}{|l|}{ Urban size: } \\
\hline High degree urb. & 0.447 & 0.497 & 0.593 & 0.491 & 0.641 & 0.480 \\
\hline Medium degree urb. & 0.327 & 0.469 & 0.208 & 0.406 & 0.257 & 0.437 \\
\hline Small degree urb. & 0.226 & 0.418 & 0.198 & 0.399 & 0.102 & 0.302 \\
\hline
\end{tabular}


Table A.1. Weighted descriptive statistics (continuation)

\begin{tabular}{lcccccc}
\hline & \multicolumn{2}{c}{ Natives } & \multicolumn{2}{c}{ Immigrant from EU } & \multicolumn{2}{c}{ Immigrant from outside EU } \\
\cline { 2 - 7 } Variable & Mean & Std. Dev & Mean & Std. Dev & Mean & Std. Dev \\
\hline Countries: & & & & & & \\
AT & 0.036 & 0.187 & 0.046 & 0.209 & 0.041 & 0.199 \\
BE & 0.027 & 0.163 & 0.040 & 0.197 & 0.013 & 0.114 \\
CY & 0.003 & 0.058 & 0.005 & 0.073 & 0.003 & 0.058 \\
CZ & 0.062 & 0.241 & 0.030 & 0.170 & 0.005 & 0.068 \\
DE & 0.355 & 0.479 & 0.413 & 0.493 & 0.447 & 0.497 \\
DK & 0.023 & 0.149 & 0.047 & 0.211 & 0.003 & 0.055 \\
EE & 0.005 & 0.073 & 0.001 & 0.038 & 0.017 & 0.130 \\
ES & 0.115 & 0.319 & 0.134 & 0.341 & 0.150 & 0.358 \\
FR & 0.266 & 0.442 & 0.177 & 0.382 & 0.200 & 0.400 \\
GR & 0.026 & 0.159 & 0.015 & 0.123 & 0.024 & 0.153 \\
LT & 0.016 & 0.125 & 0.002 & 0.044 & 0.015 & 0.122 \\
LV & 0.009 & 0.093 & 0.006 & 0.075 & 0.015 & 0.123 \\
PT & 0.012 & 0.109 & 0.024 & 0.152 & 0.019 & 0.136 \\
SE & 0.040 & 0.197 & 0.059 & 0.235 & 0.039 & 0.195 \\
SI & 0.004 & 0.065 & 0.001 & 0.038 & 0.008 & 0.090 \\
\hline Observations & 30149 & & 929 & & 1770 & \\
\hline
\end{tabular}


Table A.2. Detailed Yun decomposition of the difference in the probability of overeducation and horizontal mismatch between immigrants and natives (continues)

\begin{tabular}{|c|c|c|c|c|c|c|}
\hline \multirow[b]{3}{*}{ VARIABLES } & \multicolumn{4}{|c|}{ Overeducation } & \multirow{2}{*}{\multicolumn{2}{|c|}{$\begin{array}{l}\text { Horizontal mismatch } \\
\text { Immigrants from non-EU } \\
\text { countries vs. natives }\end{array}$}} \\
\hline & \multicolumn{2}{|c|}{$\begin{array}{l}\text { Immigrants from EU } \\
\text { countries vs. natives }\end{array}$} & \multicolumn{2}{|c|}{$\begin{array}{c}\text { Immigrants from non-EU } \\
\text { countries vs. natives }\end{array}$} & & \\
\hline & $E$ & $\mathrm{C}$ & $E$ & $\mathrm{C}$ & $E$ & $\mathrm{C}$ \\
\hline Total dif. Between groups & \multicolumn{2}{|c|}{$\begin{array}{c}0.0705^{* * *} \\
{[0.0187]}\end{array}$} & \multicolumn{2}{|c|}{$\begin{array}{l}0.112^{* * *} \\
{[0.0135]}\end{array}$} & \multicolumn{2}{|c|}{$\begin{array}{c}0.0641^{* * *} \\
{[0.0200]}\end{array}$} \\
\hline Total & $\begin{array}{c}0.0364 * * * \\
{[0.0113]}\end{array}$ & $\begin{array}{l}0.0342 * \\
{[0.0183]}\end{array}$ & $\begin{array}{c}0.0138 \\
{[0.0130]}\end{array}$ & $\begin{array}{c}0.0979 * * * \\
{[0.0170]}\end{array}$ & $\begin{array}{l}0.00666 \\
{[0.0167]}\end{array}$ & $\begin{array}{c}0.0574^{* *} \\
{[0.0245]}\end{array}$ \\
\hline Male & $\begin{array}{c}-0.00441 * * * \\
{[0.00147]}\end{array}$ & $\begin{array}{l}-0.172 \\
{[0.420]}\end{array}$ & $\begin{array}{l}-0.00542 \\
{[0.00429]}\end{array}$ & $\begin{array}{c}-0.0279 * * \\
{[0.0119]}\end{array}$ & $\begin{array}{l}0.000160 \\
{[0.00119]}\end{array}$ & $\begin{array}{c}-0.000526 \\
{[0.0133]}\end{array}$ \\
\hline Female & $\begin{array}{c}-0.00441 * * * \\
{[0.00147]}\end{array}$ & $\begin{array}{c}0.160 \\
{[0.392]}\end{array}$ & $\begin{array}{l}-0.00542 \\
{[0.00429]}\end{array}$ & $\begin{array}{c}0.0260 * * \\
{[0.0111]}\end{array}$ & $\begin{array}{l}0.000160 \\
{[0.00119]}\end{array}$ & $\begin{array}{l}0.000491 \\
{[0.0124]}\end{array}$ \\
\hline Age & $\begin{array}{c}-0.000117^{* *} \\
{[4.76 \mathrm{e}-05]}\end{array}$ & $\begin{array}{c}1.616 \\
{[3.834]}\end{array}$ & $\begin{array}{l}-0.00415 \\
{[0.00303]}\end{array}$ & $\begin{array}{c}0.325^{* * *} \\
{[0.105]}\end{array}$ & $\begin{array}{l}-0.00219 \\
{[0.00266]}\end{array}$ & $\begin{array}{c}0.0587 \\
{[0.0966]}\end{array}$ \\
\hline \multicolumn{7}{|l|}{ Level of education: } \\
\hline Isced 3 & $\begin{array}{c}3.25 \mathrm{e}-05 * * * \\
{[5.44 \mathrm{e}-06]}\end{array}$ & $\begin{array}{l}-0.0565 \\
{[0.160]}\end{array}$ & $\begin{array}{l}-0.0214 \\
{[0.0133]}\end{array}$ & $\begin{array}{c}-0.107^{* * *} \\
{[0.0218]}\end{array}$ & $\begin{array}{c}0.000339 \\
{[0.000790]}\end{array}$ & $\begin{array}{l}-0.00947 \\
{[0.0199]}\end{array}$ \\
\hline Isced 4 & $\begin{array}{c}-0.00975 * * * \\
{[0.00170]}\end{array}$ & $\begin{array}{c}0.0236 \\
{[0.0609]}\end{array}$ & $\begin{array}{c}-0.0113 \\
{[0.00722]}\end{array}$ & $\begin{array}{c}0.0223 * * * \\
{[0.00490]}\end{array}$ & $\begin{array}{l}-1.34 \mathrm{e}-05 \\
{[0.000398]}\end{array}$ & $\begin{array}{r}-0.000274 \\
{[0.00458]}\end{array}$ \\
\hline Isced 5\&6 & $\begin{array}{c}-0.00326 * * * \\
{[0.00100]}\end{array}$ & $\begin{array}{l}-0.0801 \\
{[0.207]}\end{array}$ & $\begin{array}{c}0.00515 \\
{[0.00358]}\end{array}$ & $\begin{array}{c}-0.0355^{* *} \\
{[0.0159]}\end{array}$ & $\begin{array}{c}0.000232 \\
{[0.000479]}\end{array}$ & $\begin{array}{l}0.00851 \\
{[0.0154]}\end{array}$ \\
\hline NFE & $\begin{array}{c}-1.52 \mathrm{e}-05 \\
{[0.000377]}\end{array}$ & $\begin{array}{c}0.0207 \\
{[0.0625]}\end{array}$ & $\begin{array}{c}0.00307 \\
{[0.00421]}\end{array}$ & $\begin{array}{l}-0.00271 \\
{[0.0116]}\end{array}$ & $\begin{array}{c}0.00170 \\
{[0.00318]}\end{array}$ & $\begin{array}{l}-0.0147 \\
{[0.0144]}\end{array}$ \\
\hline No NFE & $\begin{array}{c}-1.52 \mathrm{e}-05 \\
{[0.000377]}\end{array}$ & $\begin{array}{l}-0.0175 \\
{[0.0529]}\end{array}$ & $\begin{array}{c}0.00307 \\
{[0.00421]}\end{array}$ & $\begin{array}{c}0.00229 \\
{[0.00982]}\end{array}$ & $\begin{array}{c}0.00170 \\
{[0.00318]}\end{array}$ & $\begin{array}{c}0.0124 \\
{[0.0122]}\end{array}$ \\
\hline \multicolumn{7}{|l|}{ Field of education: } \\
\hline Education & $\begin{array}{c}0.00245 \\
{[0.00179]}\end{array}$ & $\begin{array}{l}0.00153 \\
{[0.0231]}\end{array}$ & $\begin{array}{c}0.00382 \\
{[0.00303]}\end{array}$ & $\begin{array}{c}0.00205 \\
{[0.00448]}\end{array}$ & $\begin{array}{l}-0.00317 \\
{[0.00342]}\end{array}$ & $\begin{array}{l}0.0100 * * * \\
{[0.00372]}\end{array}$ \\
\hline Humanities & $\begin{array}{c}0.00306 \\
{[0.00260]}\end{array}$ & $\begin{array}{l}0.00648 \\
{[0.0222]}\end{array}$ & $\begin{array}{c}0.000136 \\
{[0.000182]}\end{array}$ & $\begin{array}{l}-0.00119 \\
{[0.00327]}\end{array}$ & & \\
\hline Social Science & $\begin{array}{c}0.00659 \\
{[0.00476]}\end{array}$ & $\begin{array}{c}-0.101 \\
{[0.261]}\end{array}$ & $\begin{array}{l}-0.00237 \\
{[0.00352]}\end{array}$ & $\begin{array}{l}0.00351 \\
{[0.0121]}\end{array}$ & $\begin{array}{l}0.00973 \\
{[0.0102]}\end{array}$ & $\begin{array}{c}0.0368 * * \\
{[0.0176]}\end{array}$ \\
\hline Science & $\begin{array}{c}0.000215 \\
{[0.000591]}\end{array}$ & $\begin{array}{c}0.0146 \\
{[0.0378]}\end{array}$ & $\begin{array}{c}0.00219 \\
{[0.00208]}\end{array}$ & $\begin{array}{l}0.00653^{*} \\
{[0.00356]}\end{array}$ & $\begin{array}{c}0.00595 \\
{[0.00609]}\end{array}$ & $\begin{array}{l}-0.00675 \\
{[0.00708]}\end{array}$ \\
\hline Engineering & $\begin{array}{l}-0.00994 \\
{[0.00633]}\end{array}$ & $\begin{array}{l}-0.126 \\
{[0.297]}\end{array}$ & $\begin{array}{l}-0.00328 \\
{[0.00428]}\end{array}$ & $\begin{array}{l}-0.0151 \\
{[0.0140]}\end{array}$ & $\begin{array}{l}-0.0153 \\
{[0.0159]}\end{array}$ & $\begin{array}{c}-0.0365^{* *} \\
{[0.0163]}\end{array}$ \\
\hline Agriculture & $\begin{array}{l}-0.00183^{*} \\
{[0.000948]}\end{array}$ & $\begin{array}{c}0.0187 \\
{[0.0471]}\end{array}$ & $\begin{array}{l}-0.000452 \\
{[0.000375]}\end{array}$ & $\begin{array}{c}0.00257 \\
{[0.00226]}\end{array}$ & & \\
\hline Health & $\begin{array}{l}0.00381^{*} \\
{[0.00221]}\end{array}$ & $\begin{array}{c}-0.0392 \\
{[0.0959]}\end{array}$ & $\begin{array}{c}0.00724 \\
{[0.00503]}\end{array}$ & $\begin{array}{l}-0.0185 * * \\
{[0.00767]}\end{array}$ & $\begin{array}{c}0.00322 \\
{[0.00331]}\end{array}$ & $\begin{array}{l}-0.00386 \\
{[0.00641]}\end{array}$ \\
\hline Services & $\begin{array}{c}-0.000102 \\
{[0.000110]}\end{array}$ & $\begin{array}{l}-0.00302 \\
{[0.0178]}\end{array}$ & $\begin{array}{c}0.00123 \\
{[0.00208]}\end{array}$ & $\begin{array}{l}-0.00240 \\
{[0.00511]}\end{array}$ & $\begin{array}{c}0.00143 \\
{[0.00173]}\end{array}$ & $\begin{array}{l}-0.00216 \\
{[0.00526]}\end{array}$ \\
\hline \multicolumn{7}{|l|}{ Economic activity: } \\
\hline Agriculture & $\begin{array}{l}-0.00149 * \\
{[0.000835]}\end{array}$ & $\begin{array}{l}0.00926 \\
{[0.0229]}\end{array}$ & $\begin{array}{c}-3.49 e-05 \\
{[0.000344]}\end{array}$ & $\begin{array}{l}-0.000470 \\
{[0.00123]}\end{array}$ & $\begin{array}{l}-0.000761 \\
{[0.000807]}\end{array}$ & $\begin{array}{c}0.00537 * * * \\
{[0.00131]}\end{array}$ \\
\hline Industry & $\begin{array}{l}-0.000168 \\
{[0.000460]}\end{array}$ & $\begin{array}{l}0.00393 \\
{[0.0501]}\end{array}$ & $\begin{array}{c}0.00106 \\
{[0.00189]}\end{array}$ & $\begin{array}{l}0.00167 \\
{[0.0107]}\end{array}$ & $\begin{array}{l}-0.00220 \\
{[0.00251]}\end{array}$ & $\begin{array}{c}-0.0277^{* *} \\
{[0.0115]}\end{array}$ \\
\hline Construction & $\begin{array}{c}0.00556^{* *} \\
{[0.00244]}\end{array}$ & $\begin{array}{c}0.0374 \\
{[0.0903]}\end{array}$ & $\begin{array}{c}0.00358 \\
{[0.00286]}\end{array}$ & $\begin{array}{c}0.00631^{* *} \\
{[0.00315]}\end{array}$ & $\begin{array}{l}-0.00305 \\
{[0.00331]}\end{array}$ & $\begin{array}{c}-0.000709 \\
{[0.00317]}\end{array}$ \\
\hline Market services & $\begin{array}{c}-0.00889 * * \\
{[0.00379]}\end{array}$ & $\begin{array}{l}-0.143 \\
{[0.337]}\end{array}$ & $\begin{array}{l}0.000418 \\
{[0.00220]}\end{array}$ & $\begin{array}{l}0.00165 \\
{[0.0124]}\end{array}$ & $\begin{array}{l}-0.00196 \\
{[0.00211]}\end{array}$ & $\begin{array}{c}-0.0507 * * * \\
{[0.0170]}\end{array}$ \\
\hline Non-market services & $\begin{array}{c}0.0296 * * * \\
{[0.00598]}\end{array}$ & $\begin{array}{l}-0.350 \\
{[0.843]}\end{array}$ & $\begin{array}{c}0.0190 \\
{[0.0135]}\end{array}$ & $\begin{array}{c}-0.0290 \\
{[0.0189]}\end{array}$ & $\begin{array}{c}0.00558 \\
{[0.00665]}\end{array}$ & $\begin{array}{c}-0.0547 * * * \\
{[0.0186]}\end{array}$ \\
\hline Tenure & $\begin{array}{l}0.0192^{* *} \\
{[0.00795]}\end{array}$ & $\begin{array}{l}-0.224 \\
{[0.583]}\end{array}$ & $\begin{array}{c}0.0513 * * \\
{[0.0257]}\end{array}$ & $\begin{array}{c}-0.0843^{* *} \\
{[0.0385]}\end{array}$ & $\begin{array}{c}0.0159 \\
{[0.0204]}\end{array}$ & $\begin{array}{l}-0.0166 \\
{[0.0365]}\end{array}$ \\
\hline
\end{tabular}


Table A.2. Detailed Yun decomposition of the probability of overeducation and horizontal mismatch between immigrants and natives (continuation)

\begin{tabular}{|c|c|c|c|c|c|c|}
\hline \multirow[b]{3}{*}{ VARIABLES } & \multicolumn{4}{|c|}{ Overeducation } & \multirow{2}{*}{\multicolumn{2}{|c|}{$\begin{array}{c}\text { Horizontal mismatch } \\
\text { Immigrants from non-EU } \\
\text { countries vs. natives }\end{array}$}} \\
\hline & \multicolumn{2}{|c|}{$\begin{array}{l}\text { Immigrants from EU } \\
\text { countries vs. natives }\end{array}$} & \multicolumn{2}{|c|}{$\begin{array}{c}\text { Immigrants from non-EU } \\
\text { countries vs. natives }\end{array}$} & & \\
\hline & $\mathrm{E}$ & $\mathrm{C}$ & $E$ & $\mathrm{C}$ & $\mathrm{E}$ & $\mathrm{C}$ \\
\hline \multicolumn{7}{|l|}{ Firm size: } \\
\hline \multirow[t]{2}{*}{ More than 10 workers } & 0.000580 & -0.0672 & $-7.56 e-05$ & 0.0205 & -0.00138 & $0.0516^{* * *}$ \\
\hline & {$[0.000384]$} & [0.172] & {$[0.00131]$} & [0.0191] & {$[0.00155]$} & [0.0195] \\
\hline \multirow[t]{2}{*}{10 workers or less } & 0.000580 & 0.0182 & $-7.56 e-05$ & -0.00555 & -0.00138 & $-0.0140 * * *$ \\
\hline & [0.000384] & [0.0465] & {$[0.00131]$} & {$[0.00517]$} & {$[0.00155]$} & {$[0.00527]$} \\
\hline \multicolumn{7}{|l|}{ Urban size: } \\
\hline \multirow[t]{2}{*}{ High degree urb. } & -0.00102 & 0.00722 & -0.00705 & -0.00702 & 0.000112 & -0.00237 \\
\hline & [0.00412] & {$[0.0604]$} & {$[0.00904]$} & {$[0.0125]$} & [0.00339] & [0.0149] \\
\hline \multirow[t]{2}{*}{ Medium degree urb. } & 0.00298 & -0.0373 & 0.00416 & -0.0163 & -0.000652 & 0.00707 \\
\hline & {$[0.00345]$} & [0.102] & [0.00395] & [0.0113] & {$[0.00167]$} & [0.0134] \\
\hline \multirow[t]{2}{*}{ Small degree urb. } & -0.000889 & 0.0221 & -0.0119 & $0.0148^{*}$ & 0.00123 & -0.00369 \\
\hline & [0.000943] & {$[0.0620]$} & [0.0107] & {$[0.00887]$} & [0.00329] & [0.00907] \\
\hline \multicolumn{7}{|l|}{ Countries: } \\
\hline \multirow[t]{2}{*}{ AT } & -0.000755 & -0.0104 & 0.000753 & $0.00482 * *$ & 0.000248 & 0.00252 \\
\hline & [0.000604] & [0.0265] & [0.000581] & {$[0.00193]$} & [0.000287] & [0.00189] \\
\hline \multirow[t]{2}{*}{$\mathrm{BE}$} & 0.000107 & 0.00455 & -0.00132 & 0.00315 & $-6.66 e-05$ & -0.00173 \\
\hline & [0.000912] & {$[0.0150]$} & [0.00193] & {$[0.00266]$} & {$[0.000628]$} & [0.00234] \\
\hline \multirow[t]{2}{*}{$\mathrm{CY}$} & $0.000252 * * *$ & 0.000952 & $1.04 \mathrm{e}-05$ & 0.000275 & $1.02 \mathrm{e}-06$ & 0.000107 \\
\hline & [9.74e-05] & {$[0.00250]$} & [7.41e-06] & [0.000201] & [1.93e-06] & [0.000210] \\
\hline \multirow[t]{2}{*}{$\mathrm{CZ}$} & 0.000829 & -0.0142 & -0.00957 & 0.00630 & -0.00594 & $0.0140 * *$ \\
\hline & [0.00186] & [0.0368] & [0.0104] & {$[0.00638]$} & [0.00567] & [0.00594] \\
\hline \multirow[t]{2}{*}{$\mathrm{DE}$} & -0.00227 & -0.0767 & -0.0164 & $-0.0568 * * *$ & -0.00350 & -0.0175 \\
\hline & [0.00305] & {$[0.216]$} & [0.0124] & [0.0194] & [0.00387] & [0.0181] \\
\hline \multirow[t]{2}{*}{ DK } & -0.000573 & -0.00893 & -0.00226 & 0.000176 & 0.00359 & -0.00587 \\
\hline & [0.00128] & [0.0207] & {$[0.00527]$} & {$[0.00462]$} & {$[0.00437]$} & [0.00473] \\
\hline \multirow[t]{2}{*}{$\mathrm{EE}$} & $0.000632^{*}$ & -0.00240 & -0.00173 & -0.000242 & -0.000237 & -0.000326 \\
\hline & [0.000384] & [0.00601] & {$[0.00121]$} & [0.000255] & [0.000349] & [0.000228] \\
\hline \multirow[t]{2}{*}{ ES } & $0.00533 * * *$ & 0.104 & 0.0130 & $0.0238 * * *$ & 0.000241 & -0.00480 \\
\hline & [0.00104] & {$[0.246]$} & [0.00829] & {$[0.00605]$} & [0.000872] & [0.00507] \\
\hline FR & -0.000790 & -0.00705 & 0.00188 & -0.0113 & -0.00248 & 0.000817 \\
\hline & {$[0.00422]$} & [0.0592] & {$[0.00354]$} & [0.0115] & {$[0.00259]$} & [0.0112] \\
\hline GR & -0.000875 & 0.0143 & -0.000977 & $0.0118^{* * *}$ & -0.000241 & $0.00591^{* * *}$ \\
\hline & [0.000865] & [0.0346] & [0.000658] & {$[0.00222]$} & [0.000256] & [0.00226] \\
\hline LT & 0.00253 & 0.00282 & 0.000826 & $-0.00929 * * *$ & $2.57 \mathrm{e}-05$ & -0.00154 \\
\hline & {$[0.00320]$} & [0.0164] & {$[0.000543]$} & [0.00208] & [3.33e-05] & {$[0.00109]$} \\
\hline LV & 0.000692 & -0.00413 & -0.00351 & $-0.00252 * * *$ & $-7.87 e-05$ & 0.000228 \\
\hline & [0.000667] & [0.0133] & {$[0.00242]$} & {$[0.000850]$} & {$[0.000235]$} & [0.000634] \\
\hline PT & $0.00168 * *$ & 0.00482 & 0.000453 & -0.000146 & -0.000176 & -0.000640 \\
\hline & {$[0.000770]$} & {$[0.0126]$} & {$[0.000591]$} & [0.000839] & [0.000281] & [0.000839] \\
\hline SE & 0.00129 & -0.00724 & -0.000207 & 0.00211 & $-1.38 \mathrm{e}-06$ & 0.00154 \\
\hline & [0.00128] & [0.0200] & [0.000137] & {$[0.00280]$} & [2.90e-05] & {$[0.00265]$} \\
\hline SI & $-3.00 e-05$ & -0.00105 & 0.000278 & -0.000127 & -0.000123 & $-6.62 e-06$ \\
\hline & [0.000432] & {$[0.00364]$} & [0.000302] & {$[0.000266]$} & [0.000153] & [0.000269] \\
\hline Constant & & -0.510 & & 0.0436 & & 0.118 \\
\hline & & [1.316] & & [0.0999] & & [0.0973] \\
\hline Observations & 31078 & 31078 & 31919 & 31919 & 31919 & 31919 \\
\hline
\end{tabular}

All models are estimated using survey weights. Standard errors are reported between brackets.

$*$ p-value $<10 \% * *$ p-value $<5 \% * * *$ p-value $<1 \%$ 